\title{
Agro-Economic Implications of Combined Application of Organic and Mineral Fertilizers on Maize
}

\author{
Ngoran Eveline Banye ${ }^{1^{*}}\left(\mathbb{D}\right.$, Tabi Oben Fritz ${ }^{2}$, Nguetsop Victor François ${ }^{1}$ \\ ${ }^{1}$ Research Unit of Applied Botany, Faculty of Sciences, University of Dschang, Dschang, Cameroon \\ ${ }^{2}$ Research Unit of Soil Analysis and Environmental Chemistry, Faculty of Agronomy and Agricultural Sciences, University of \\ Dschang, Dschang, Cameroon \\ Email: *ngoraneveline@yahoo.com
}

How to cite this paper: Banye, N.E., Fritz, T.O. and François, N.V. (2020) Agro-Economic Implications of Combined Application of Organic and Mineral Fertilizers on Maize. Agricultural Sciences, 11, 638-652. https://doi.org/10.4236/as.2020.117041

Received: June 20, 2020

Accepted: July 25, 2020

Published: July 28, 2020

Copyright ( 2020 by author(s) and Scientific Research Publishing Inc. This work is licensed under the Creative Commons Attribution International License (CC BY 4.0).

http://creativecommons.org/licenses/by/4.0/ (c) (i) Open Access

\begin{abstract}
Continuous cultivation without adequate fertilizer application is responsible for plant nutrient depletion and yield decline of major food crops in sub-Saharan Africa. Field experiments were conducted on umbric Cambisol in Babungo and ustic Oxisol in Bansoa in the Western Highlands of Cameroon over two years to evaluate the effects of combined application of leaf biomass of agroforestry species and mineral fertilizers with their economic returns on maize yield performance. Ten treatments encompassing sole mineral fertilizer, sole leaf biomass of Calliandra, Leucaena, Acacia and Cassia, leaf biomasses combined with mineral fertilizer and absolute control were laid in a randomized complete block design and replicated three times. Data collected on maize grain yield was subjected to analysis of variance using XLSTAT version 2014 statistical software. In addition, an economic analysis was performed to evaluate the profitability of the different treatment combinations. The results showed significant differences $(P \leq 0.05)$ amongst the different treatments on maize yield on both soil types. The highest maize yields which stood at $5.93 \mathrm{t} / \mathrm{ha}$ and $6.01 \mathrm{t} / \mathrm{ha}$ were recorded in plots treated with Acacia and Cassia plus half recommended mineral fertilizer on umbric Cambisol and ustic Oxisol respectively. Economic analyses showed that Acacia and Cassia plus half recommended mineral fertilizer gave the highest net benefit and return to labor of 286500 FCFA and 5.1 on umbric Cambisol and 296051 FCFA and 5.3 on ustic Oxisol respectively. On both soils, all the treatments except Calliandra with half recommended mineral fertilizers were economically profitable with benefit to cost ratios that ranged from 2.02 to 2.92. Combined application of agroforestry tree species leaf biomass and mineral fertilizers is an appropriate technology to enhance maize grain yield and is economically profitable except Calliandra with half recommended
\end{abstract}


mineral fertilizers and is therefore recommended for degraded Cambisols and Oxisols in the Western Highlands of Cameroon.

\section{Keywords}

Benefit Cost Ratio, Economic Analysis, Maize Yield, Net Benefit, Profitability

\section{Introduction}

Maize (Zea mays L.) is a quick growing $\mathrm{C}_{4}$ plant of the Poaceae family. Among cereals, it is an important food and feed crop which ranks third after wheat and rice in [1]. According to Ragasa et al. [2], the bulk of maize produced in sub-Saharan Africa (SSA) goes into food consumption making it an important crop for food security. Because of its expanded use in the agro-industries, it is recognized as a leading commercial crop of great agro-economic values. Despite the entire benefits and availability of improved germplasm, average maize yield in SSA including the Western Highlands of Cameroon (WHC) remains one of the lowest $(1.6 \mathrm{t} / \mathrm{ha})$ in the world [3].

In most parts of SSA including Cameroon, the inherent poor fertility status, continuous cultivation without adequate supply of nutrients, soil erosion, lack of soil fertility restoring practices and nutrient mining especially $\mathrm{N}$ and $\mathrm{P}$ are major reasons for plant nutrient depletion and yield decline of major food crops including maize [4] [5]. Unsustainable farming activities have led to nutrient depletion and the overall result has been a decline in land productivity and massive environmental degradation all contributing to malnutrition and food insecurity [6]. In order to obtain high maize yield and sustain productivity, the soil's nutrient status needs to be increased [7].

Application of inorganic fertilizers is widely used globally to overcome nutrient deficiencies and dramatic increases in yields of several crops have been obtained [8]. However, their use remains very low in SSA including the WHC and ineffective for sustaining crop production and maintaining soil fertility because they are not affordable and accessible to poor resource farmers [9]. Moreover, continuous use of inorganic fertilizers acidifies the soil, promotes cation loss and depletes macronutrients through losses in gaseous form and by leaching especially when recommended doses are not respected [8]. Since resource-limited farmers cannot afford inorganic fertilizers because of high prices and consequently low profit margins, it is necessary to seek for affordable and less risky nutrient management practices that contain necessary ingredients for superior performance [10] [11]. Greater yield benefits can be achieved following the combined application of organic resources and mineral fertilizers compared to either resource applied singly [11] [12]. Combined application of organic materials and inorganic fertilizers enhanced carbon storage in soils and reduced emissions from nitrogen fertilizer use while contributing to high crop productiv- 
ity in agriculture [13]. According to Abdelzaher et al. [12], integrated application of organic and inorganic fertilizer increased the growth and yield of maize than when any of the fertilizer was used alone. Improved application methods targeting inorganic fertilizers and organic inputs do not only conserve nutrients in the soil, but also increase nutrient uptake efficiency [14] [15] and the long-term build ecologically sound and viable crop production and farming systems [8] [16]. Organic fertilizers can improve soil physicochemical properties, increase yield for major food crops and favor nutrient cycling through mineralization or immobilization turnover of added matter [17] [18] [19]. Organic resources play an essential role in soil fertility management in the tropics by their short-term effects on nutrient supply and long-term contribution to soil organic matter formation [20].

Leaf biomass of Calliandra calothyrsus, Leucaena leucocephala, Acacia angustissima and Cassia spectabilis hereafter referred to as: Calliandra spp., Leucaena spp., Acacia spp. and Cassia spp. respectively are some organic resources used in soil management practices in the WHC [4] [5] even though at very low application rates. Although, recommendations of the use of agroforestry tree biomass for soil fertility restoration and climate change adaptation abound, adaptation in the WHC remains low.

In the study area, apart from works carried out to examine the effects of green manure and NPK fertilizer on the growth and yield of maize in the mount Cameroon region by Egbe et al. [4] and the effect of tree hedgerow pruning on maize yield by Neba et al. [5], information on the effect of application of these organic materials and inorganic fertilizers into the soil on maize yield performance as well as their economic returns is scarce. However, adoption of any new technology depends on farmer's perceptions of financial benefits, particularly when additional labor is required in the establishment and management of these technologies [18].

It is against this backdrop that this study was therefore established in the two main maize growing areas of the WHC in 2018 and 2019 with the main objective of bringing closer, feasible soil nutrient replenishment technologies to resource-limited farmers to increase soil fertility and enhance food security through maize production. More specifically, the study was designed to:

Establish the interactive effect on the combined use of leaf biomass of Calliandra spp., Leucaena spp., Acacia spp. and Cassia spp. and inorganic fertilizers into soils on maize yield;

Evaluate the economic returns of combined application of leaf biomass of Calliandra spp., Leucaena spp., Acacia spp. and Cassia spp. and mineral fertilizer with maize as test crop in the WHC.

\section{Materials and Methods}

\subsection{Location and Description of Study Sites}

Agronomic experiments were conducted on-farm under rain-fed conditions 
during two cropping seasons (2018 and 2019) in two sites: the experimental plot of the Institute of Agricultural Research for Development (IRAD), Babungo in the North-West region and the Teaching and Research farm of the Department of Agronomy at Bansoa in the West region, Cameroon. The growing period covered end-March to mid-September. Babungo is located between longitudes $15^{\circ} 25^{\prime} \mathrm{E}$ and $15^{\circ} 30^{\prime} \mathrm{E}$ and between latitudes $5^{\circ} 4^{\prime}$ and $5^{\circ} 10^{\prime} \mathrm{N}$ and situated at an altitude of about 300 meters above sea level while Bansoa is located between longitude $10^{\circ} 15^{\prime} \mathrm{E}$ and latitude $05^{\circ} 25^{\prime} \mathrm{N}$ and situated at an altitude of about 1414 meters above sea level. The areas have mean monomodal annual rainfall and temperature of approximately $1600 \mathrm{~mm}$ and $27.2^{\circ} \mathrm{C}$ for Babungo and $1936 \mathrm{~mm}$ and $20.4^{\circ} \mathrm{C}$ for Bansoa respectively. The soil of Babungo which is sandy clay loam is broadly classified as umbric Cambisol while that of Bansoa is sandy loam and classified as ustic Oxisol [21] [22]. The results of soil analyses before the start of experiments showed that they were acidic, high in organic matter, low in total $\mathrm{N}$ and available $\mathrm{P}$ as shown in Table 1.

\subsection{Plant Material, Organic and Mineral Fertilizers Used in the Study}

Plant material used in the study was maize composite seed variety (Cameroon Highlands Composite) CHC 202 with yellow flint due to its adaptability to acidic soil of the western highlands agro-ecological zone purchased from IRAD Dschang. According to inquiries with agronomist and farmers in the study areas, it is a variety of great agronomic performance since it is tolerant to leaf blights,

Table 1. Physicochemical properties of soils before experimentation.

\begin{tabular}{ccc}
\hline Parameters & \multicolumn{2}{c}{ Sites } \\
\cline { 2 - 3 } & Babungo & Bansoa \\
\hline pH-water & 4.10 & 5.20 \\
Nitrogen (\%) & 0.09 & 0.13 \\
Organic Matter (\%) & 5.70 & 6.00 \\
C/N & 36.00 & 37.30 \\
Phosphorus (ppm) & 10.61 & 15.8 \\
Potassium (mg/kg $\left.{ }^{-1}\right)$ & 1.20 & 1.20 \\
Calcium (mg/kg $\left.{ }^{-1}\right)$ & 7.40 & 11.40 \\
CEC (mg/kg $\left.{ }^{-1}\right)$ & 41.10 & 38.70 \\
Sand (\%) & 45.70 & 62.30 \\
Silt (\%) & 26.30 & 20.70 \\
Clay (\%) & 28.00 & 17.00 \\
Textural class & Sandy clay loam & Sandy loam \\
Soil type & umbric Cambisol & ustic Oxisol \\
Bulk Density (g/cm & 0.98 & 0.98 \\
\hline
\end{tabular}


smuts, maize streak virus diseases and highland rust and can produce about 7 - 8 t/ha. It attains maturity at about 135 - 150 days. Organic and mineral fertilizers used were fresh leaves of Calliandra spp., Leucaena spp., Acacia spp. and Cassia spp. collected from already established fields at Ndop and Dschang, tertiary fertilizer composed of NPK (3 345 ), NPK (14 24 14) + 3.5 MgO and Urea purchased from agro-retailers in the study areas.

\subsection{Experimental Procedures}

\subsubsection{Experimental Design, Field Experiments and Agronomic Practices}

The experiments were conducted on umbric Cambisol and ustic Oxisol. The experimental fields were plowed once for each of the two cropping seasons. The lay out was a Randomized Complete Block Design (RCBD) with three replications. The size of the plot per treatment was $3 \times 4$ meters $\left(12 \mathrm{~m}^{2}\right)$ with 50 and $100 \mathrm{~cm}$ paths separating adjacent plots and blocks, respectively. Sample of each organic input was taken and the amounts equivalent to $100 \mathrm{~N}+75 \mathrm{P}_{2} \mathrm{O}_{5}+90 \mathrm{~K}_{2} \mathrm{O} \mathrm{Kg} / \mathrm{ha}$ and $50 \mathrm{~N}+37.5 \mathrm{P}_{2} \mathrm{O}_{5}+45 \mathrm{~K}_{2} \mathrm{O} \mathrm{kg} / \mathrm{ha}$ was measured and applied in whole on designated plots and lightly incorporated during planting to designated plots. Maize composite seed variety (Cameroon Highlands Composite) CHC 202 was used as a test crop. Ten treatments were applied every season. The treatments comprise; $\mathrm{T}_{1}: 2$ t/ha Calliandra spp.; $\mathrm{T}_{2}: 2$ t/ha Leucaena spp.; $\mathrm{T}_{3}: 3$ t/ha Acacia spp.; $\mathrm{T}_{4}: 3$ t/ha Cassia spp.; $\mathrm{T}_{5}: 1$ t/ha Calliandra spp. $+\left(50 \mathrm{~N}+37.5 \mathrm{P}_{2} \mathrm{O}_{5}+45\right.$ $\left.\mathrm{K}_{2} \mathrm{O}\right) ; \mathrm{T}_{6}: 1 \mathrm{t} /$ ha Leucaena spp. $+\left(50 \mathrm{~N}+37.5 \mathrm{P}_{2} \mathrm{O}_{5}+45 \mathrm{~K}_{2} \mathrm{O}\right) ; \mathrm{T}_{7}: 1 \frac{1 / 2}{\mathrm{t}} / \mathrm{ha}$ Acacia spp. $+\left(50 \mathrm{~N}+37.5 \mathrm{P}_{2} \mathrm{O}_{5}+45 \mathrm{~K}_{2} \mathrm{O}\right) ; \mathrm{T}_{8}: 11 \frac{1 / 2}{\mathrm{t}} / \mathrm{ha}$ Cassia spp. $+\left(50 \mathrm{~N}+37.5 \mathrm{P}_{2} \mathrm{O}_{5}\right.$ $+45 \mathrm{~K}_{2} \mathrm{O}$ ); $\mathrm{T}_{9}: 100 \mathrm{~N}+75 \mathrm{P}_{2} \mathrm{O}_{5}+90 \mathrm{~K}_{2} \mathrm{O} \mathrm{Kg} / \mathrm{ha}$ and $\mathrm{T}_{10}$ : absolute control. The $100 \mathrm{~N} \mathrm{~kg}$ /ha inorganic fertilizer treatment (in the form of NPK (3 345$)$ ), NPK (14 $2414)+3.5 \mathrm{MgO}$ and urea) was split applied on the designated plots at 21 and 45 days after planting (DAP) using $40 \%$ and $60 \%$ of the total fertilizer respectively, while $75 \mathrm{P}_{2} \mathrm{O}_{5} \mathrm{Kg} / \mathrm{ha}$ and $90 \mathrm{~K}_{2} \mathrm{O} \mathrm{Kg} /$ ha were entirely applied at $21 \mathrm{DAP}$. Weeding was done at 4 and 12 weeks after planting. Stem borers in maize were controlled by preventive spraying of Caillemas Blue pesticide. Crop residues from the first major rainy season cropping were totally removed from the fields to reduce the confounding or residual effects of organic residues of the maize plants for the subsequent cropping major rainy season.

\subsubsection{Agronomic Data Collection}

Four weeks after planting (4 WAP), 4 maize plants in the middle rows with similar characteristics were randomly selected from each plot and tagged and data on maize yield was collected on ustic Oxisol and umbric Cambisol for each cropping season as described by Agba et al. [23] with slight modification. To determine grain yield, maize plants from each replicate were manually harvested at physiological maturity (20 WAP), peeled and oven-dried at $70^{\circ} \mathrm{C}$ inside envelopes for three days and hand-threshed. Dry maize grains were weighed on a scale balance to obtain the total yield ( $t / h a)$ and grain yield was computed in tons per hectare based on the population of plants per hectare $(62,500)$ used in 
the study. This was estimated as per the relationship described by Equation (1) Agba et al. [23] below:

$$
G Y_{h a}=Y_{P} \times P_{h a}
$$

where, $G Y_{h a}=$ Grain yield per hectare; $Y_{p}=$ Average grain yield per plant and $P_{h a}$ $=$ plant population per hectare.

\subsubsection{Economic Analysis}

Detailed data on labor requirements were collected every season for each of the field operations (land preparation, planting, fertilizer application, weeding, pest control and harvest). The time taken to perform every activity was recorded and the labor was costed at the local wage rate of Cameroon FCFA per working day (8 hours) in the study area. Other input and output prices, derived from the farm gate prices and wages in the area, and costs used in the economic analysis are presented in (Table 2).

However, since all the organic amendments were collected near the experimental plots, only the labor for harvesting, transportation and incorporation were taken into consideration [14]. A benefit cost analysis was done to evaluate the profitability of leaf biomass of agroforestry tree species and mineral fertilizer used in the experiments. The benefit to cost ratio was calculated following the procedure described by Boukong et al. [22] with slight modification based on the following costs:

- Total cost of labor (TCL) was calculated according to Equation (2):

$$
\mathrm{TCL}=\mathrm{CLP}+\mathrm{CPM}+\mathrm{CAF}+\mathrm{CAP}+\mathrm{CW}+\mathrm{CSL}
$$

where: CLP $=$ Labor cost for land preparation, $\mathrm{CPM}=$ Labor cost for planting maize, $\mathrm{CAF}=$ Cost for applying fertilizers, $\mathrm{CAP}=$ Labor cost for applying pesticide, $\mathrm{CW}=$ Labor cost for weeding and CSL $=$ Labor cost for harvesting maize.

Table 2. Parameters used to calculate the economic returns for the different soil management practices.

\begin{tabular}{lc}
\hline \multicolumn{1}{c}{ Parameter } & Actual Cost \\
\hline Labor cost for land preparation (CLP) & $20,000 \mathrm{FCFA} / \mathrm{ha}$ \\
Price of maize seed (CMS) & $12,500 \mathrm{FCFA} / \mathrm{ha}$ \\
Price of organic, mineral and both fertilizers combined (CF) & $60,000 / 198,000 / 129,000 \mathrm{FCFA} / \mathrm{ha}$ \\
Cost for applying organic, mineral and fertilizers combined & $4000 / 6000 / 8000 \mathrm{FCFA} / \mathrm{ha}$ \\
(CAF) & $5000 \mathrm{FCFA} / \mathrm{ha}$ \\
Labor cost for planting maize (CPM) & $6000 \mathrm{FCFA} / \mathrm{ha}$ \\
Price of pesticide (CP) & $3000 \mathrm{FCFA} / \mathrm{ha}$ \\
Labor cost for applying pesticide (CAP) & $16000 \mathrm{FCFA} / \mathrm{ha}$ \\
Labor cost for weeding (CW) & $6000 \mathrm{FCFA} / \mathrm{ha}$ \\
Labor cost for harvesting maize (CSL) & $1000 / 9000 \mathrm{FCFA} / \mathrm{ha}$ \\
Labor cost for transportation (leaf biomass and maize) (CT) & $2500 \mathrm{FCFA} / 15 \mathrm{~L}$ \\
Price of maize &
\end{tabular}


- Total cost of production (TCP) was calculated as shown by Equation (3):

$$
\mathrm{TCP}=\mathrm{CMS}+\mathrm{CF}+\mathrm{CP}+\mathrm{CT}+\mathrm{TCL}
$$

where: $\mathrm{CMS}=$ Price of maize seed, $\mathrm{CF}=$ Cost of fertilizers, $\mathrm{CP}=$ Cost of pesticide, $\mathrm{CT}=$ Labor cost for transportation and $\mathrm{TCL}=$ Total cost of labor.

- All costs were adjusted for interest on investment (II), calculated as shown in Equation (4) (Boukong et al.) [22] below:

$$
\mathrm{II}=\mathrm{TCP} \times 4.25 \times \frac{n}{100} N
$$

where: $n=$ number of days between first fertilizer application and last harvest (141 for leaf biomass and 120 for mineral fertilizer); $N=$ number of days in a year (365); 4.25 is the current interest rate recognized in Cameroon economy.

- Return cost of production using fertilizers and pesticide (RCPF) becomes: TCP + II.

Supplementary yield(SY)

$=$ mean yield per fertilized treatment - mean yield of control treatment

- Return cost of supplementary yield $(\mathrm{RCSY})=$ Return cost of fertilized treatments - Return cost of control treatments.

- The benefit to cost ratio (B/C) was calculated using Equation (5):

$$
\frac{\mathrm{B}}{\mathrm{C}}=\frac{\mathrm{RCSY}}{\mathrm{RCPF}}
$$

where: RCSY $=$ Return cost of supplementary yield and RCPF $=$ Return cost of fertilized treatments.

- Profitability (RT) was calculated as shown in Equation (6):

$$
\mathrm{RT}=(\mathrm{RCSY}-\mathrm{RCPF}) \times \frac{100}{\mathrm{RCPF}}
$$

where: RCSY $=$ Return cost of supplementary yield and RCPF $=$ Return cost of fertilized treatments.

- Net benefit (NB) was calculated based on Equation (7) (Mucheru-Muna et al.) [18]:

$$
\mathrm{NB}=\mathrm{RCSY}-\mathrm{TCP}
$$

where: RCSY $=$ Return cost of supplementary yield and TCP $=$ Total cost of production.

- Return to labor (RL) was calculated according to Equation (8) (Mucheru-Muna et al.) [18]:

$$
\mathrm{RL}=\mathrm{TCP}-\mathrm{TCL}
$$

where: $\mathrm{TCP}=$ Total cost of production and TCL $=$ Total cost to labor.

\subsection{Statistical and Economic Analyses of Data}

Analysis of variance was conducted using XLSTAT 2014 statistical software to compare treatment effects on maize yields. Means were separated using the student Newman keuls' Test at $5 \%$ level $(P \leq 0.05)$. In order to conduct an econom- 
ic analysis of the different treatments, partial budgeting analysis techniques was employed to evaluate the various costs and corresponding benefits of technologies used in the experiments.

\section{Results}

\subsection{Effects of Combined Application of Organic and Mineral Fertilizers on Maize Grain Yield on Umbric Cambisol and Ustic Oxisol over 2 Years}

The results of ANOVA indicated that maize grain yield varied significantly ( $P \leq$ 0.05) among treatments on umbric Cambisol and ustic Oxisol and between soil types. However, the test used in mean separation (student Newman keuls' Test) showed that there were no significant differences among sole biomass treatments as well as those combining leaf biomass and mineral fertilizer. Furthermore, the results over 2 cropping seasons showed that, 1/1/2 t/ha Acacia $+\left(50 \mathrm{~N}+37.5 \mathrm{P}_{2} \mathrm{O}_{5}\right.$ $+45 \mathrm{~K}_{2} \mathrm{O}$ ) treatment gave the highest maize grain yield followed closely by $1 \mathrm{t} / \mathrm{ha}$ Calliandra $+\left(50 \mathrm{~N}+37.5 \mathrm{P}_{2} \mathrm{O}_{5}+45 \mathrm{~K}_{2} \mathrm{O}\right)$ treatment with 5.93 and $5.80 \mathrm{t} / \mathrm{ha} \mathrm{re}-$ spectively on umbric Cambisol, while $1 \frac{1 / 2}{t} /$ ha Cassia $+\left(50 \mathrm{~N}+37.5 \mathrm{P}_{2} \mathrm{O}_{5}+45\right.$ $\mathrm{K}_{2} \mathrm{O}$ ) treatment gave the highest maize grain yield followed closely byl $\mathrm{t} / \mathrm{ha}$ Leucaena $+\left(50 \mathrm{~N}+37.5 \mathrm{P}_{2} \mathrm{O}_{5}+45 \mathrm{~K}_{2} \mathrm{O}\right)$ treatment with 6.01 and $5.92 \mathrm{t} / \mathrm{ha}$ respectively on ustic Oxisol. The absolute control treatments gave minimum maize grain yield of 1.89 and $1.93 \mathrm{t} / \mathrm{ha}$ respectively under umbric Cambisol and ustic Oxisol. Between soil types, maximum maize grain yield ( $5.15 \mathrm{t} / \mathrm{ha})$ was recorded on ustic Oxisol as shown in Table 3.

Table 3. Effects of application of treatments on maize yield on umbric Cambisol and ustic Oxisol over 2 years.

\begin{tabular}{ccc}
\hline & \multicolumn{2}{c}{ Maize grain yield (t/ha) } \\
\cline { 2 - 3 } Treatments & \multicolumn{2}{c}{ Soil types } \\
\cline { 2 - 3 } & $5.18 \pm 3.74^{\mathrm{abc}}$ & ustic Oxisol \\
\cline { 2 - 3 } T1 & $4.78 \pm 3.84^{\mathrm{c}}$ & $5.11 \pm 0.29^{\mathrm{b}}$ \\
T2 & $5.35 \pm 5.85^{\mathrm{abc}}$ & $5.21 \pm 0.44^{\mathrm{ab}}$ \\
T3 & $5.01 \pm 4.25^{\mathrm{bc}}$ & $5.55 \pm 0.34^{\mathrm{ab}}$ \\
T4 & $5.80 \pm 1.60^{\mathrm{ab}}$ & $5.34 \pm 0.13^{\mathrm{ab}}$ \\
T5 & $5.53 \pm 0.49^{\mathrm{abc}}$ & $5.92 \pm 0.46^{\mathrm{ab}}$ \\
T6 & $5.93 \pm 8.47^{\mathrm{a}}$ & $5.48 \pm 0.21^{\mathrm{ab}}$ \\
T7 & $5.40 \pm 7.68^{\mathrm{abc}}$ & $6.01 \pm 0.44^{\mathrm{a}}$ \\
T8 & $5.34 \pm 1.02^{\mathrm{abc}}$ & $5.49 \pm 0.21^{\mathrm{ab}}$ \\
T9 & $1.89 \pm 0.26^{\mathrm{d}}$ & $1.93 \pm 0.05^{\mathrm{c}}$ \\
T10 & $5.02 \pm 1.19^{\mathrm{b}}$ & $5.15 \pm 1.19^{\mathrm{a}}$ \\
Soil types & &
\end{tabular}

a,b,c: comparison of maize grain yield and soil types on application of treatments over 2 years: means in a column and those on row of soil types having different letter(s) are significantly different (student Newman Keuls' test at $P \leq 0.05)$. $\mathrm{T}_{1}: 2 \mathrm{t} / \mathrm{h}$ Calliandra; $\mathrm{T}_{2}: 2 \mathrm{t} / \mathrm{h}$; Leucaena; $\mathrm{T}_{3}: 3 \mathrm{t} / \mathrm{h}$ Acacia; $\mathrm{T}_{4}: 3 \mathrm{t} / \mathrm{h}$ Cassia; $\mathrm{T}_{5}: 1 \mathrm{t} / \mathrm{h}$ Calliandra + $\left(50 \mathrm{~N}+37.5 \mathrm{P}_{2} \mathrm{O}_{5}+45 \mathrm{~K}_{2} \mathrm{O} ; \mathrm{T}_{6}: 1 \mathrm{t} / \mathrm{h}\right.$ Leucaena $+\left(50 \mathrm{~N}+37.5 \mathrm{P}_{2} \mathrm{O}_{5}+45 \mathrm{~K}_{2} \mathrm{O}\right) ; \mathrm{T}_{7}: 1 \frac{1}{2} \mathrm{t} / \mathrm{h}$ Acacia $+\left(50 \mathrm{~N}+37.5 \mathrm{P}_{2} \mathrm{O}_{5}+45 \mathrm{~K}_{2} \mathrm{O}\right) ; \mathrm{T}_{8}: 1 \frac{1}{2} \mathrm{t} / \mathrm{h}$ Cassia $+\left(50 \mathrm{~N}+37.5 \mathrm{P}_{2} \mathrm{O}_{5}+45 \mathrm{~K}_{2} \mathrm{O}\right) ; \mathrm{T}_{9}: 100 \mathrm{~N}+75 \mathrm{P}_{2} \mathrm{O}_{5}$ $+90 \mathrm{~K}_{2} \mathrm{O} \mathrm{Kg} / \mathrm{ha} ; \mathrm{T}_{10}$ : Absolute control. 


\subsection{Economics of Combined Application of Organic and Mineral Fertilizers on Maize on Umbric Cambisol and Ustic Oxisol over 2 Years}

The results of the economic analysis varied according to the technology used in soil management practices. On the average across the two cropping seasons, $1 \frac{1}{2}$ t/ha Acacia $+\left(50 \mathrm{~N}+37.5 \mathrm{P}_{2} \mathrm{O}_{5}+45 \mathrm{~K}_{2} \mathrm{O}\right)$ treatment recorded the highest net benefit and return to labor of 286,500 FCFA and 5.1 respectively on umbric Cambisol while $1 \frac{1 / 2}{2}$ /ha Cassia $+\left(50 \mathrm{~N}+37.5 \mathrm{P}_{2} \mathrm{O}_{5}+45 \mathrm{~K}_{2} \mathrm{O}\right)$ treatment recorded the highest net benefit and return to labor of 296,051 FCFA and 5.30 respectively on ustic Oxisol. These were followed closely by $3 \mathrm{t} / \mathrm{ha}$ Acacia and Cas sia treatments with net benefit and return to labor of 286,000 FCFA and 4.90 respectively on umbric Cambisol and 296,041 FCFA and 5.10 respectively on ustic Oxisol. On the other hand, treatments that received 3 t/ha Acacia and Cassia gave maximum benefit to cost ratios of 2.84 and 2.92 respectively on umbric Cambisol and ustic Oxisol. The control treatments recorded the lowest net benefits, benefit to cost ratios and returns to labor of $-78,500$ FCFA, 0.00 and -1.60 respectively on both soils as shown in Table 4 .

\section{Discussions}

\subsection{Effects of Combined Application of Organic and Mineral Fertilizers on Maize Grain Yields on Umbric Cambisol and Ustic Oxisol over 2 Years}

Grain yield is the final result of many complex morphological and physiological

Table 4. Net benefits, benefit/cost ratios and returns to labor on umbric Cambisol and ustic Oxisol over 2 years.

\begin{tabular}{ccccccc}
\hline & \multicolumn{2}{c}{ Net benefit (FCFA) } & \multicolumn{2}{c}{ Benefit /cost ratio } & \multicolumn{2}{c}{ Return to labor } \\
\cline { 2 - 7 } Treatments & $\begin{array}{c}\text { umbric } \\
\text { Cambisol }\end{array}$ & $\begin{array}{c}\text { ustic } \\
\text { Oxisol }\end{array}$ & $\begin{array}{c}\text { umbric } \\
\text { Cambisol }\end{array}$ & $\begin{array}{c}\text { ustic } \\
\text { Oxisol }\end{array}$ & $\begin{array}{c}\text { umbric } \\
\text { Cambisol }\end{array}$ & $\begin{array}{c}\text { ustic } \\
\text { Oxisol }\end{array}$ \\
\hline T1 & 261,000 & 248,500 & 2.68 & 2.59 & 4.50 & 4.20 \\
T2 & 211,000 & 286,000 & 2.35 & 2.84 & 3.40 & 4.90 \\
T3 & 286,000 & 258,541 & 2.84 & 2.68 & 4.90 & 4.50 \\
T4 & 236,000 & 296,041 & 2.52 & 2.92 & 4.10 & 5.10 \\
T5 & 274,000 & 208,551 & 2.22 & 1.96 & 4.90 & 3.70 \\
T6 & 236,500 & 283,351 & 2.08 & 2.31 & 4.20 & 5.10 \\
T7 & 286,500 & 233,551 & 2.31 & 2.08 & 5.10 & 4.20 \\
T8 & 224,000 & 296,051 & 2.02 & 2.37 & 4.00 & 5.30 \\
T9 & 142,500 & 151,099 & 1.48 & 1.53 & 2.60 & 2.80 \\
T10 & $-78,500$ & $-78,500$ & 0.00 & 0.00 & -1.60 & -1.60 \\
\hline
\end{tabular}

$\mathrm{T}_{1}: 2 \mathrm{t} / \mathrm{h}$ Calliandra; $\mathrm{T}_{2}: 2 \mathrm{t} / \mathrm{h} ;$ Leucaena; $\mathrm{T}_{3}: 3 \mathrm{t} / \mathrm{h}$ Acacia; $\mathrm{T}_{4}: 3 \mathrm{t} / \mathrm{h}$ Cassia; $\mathrm{T}_{5}: 1 \mathrm{t} / \mathrm{h}$ Calliandra $+(50 \mathrm{~N}+37.5$ $\mathrm{P}_{2} \mathrm{O}_{5}+45 \mathrm{~K}_{2} \mathrm{O} ; \mathrm{T}_{6}: 1 \mathrm{t} / \mathrm{h}$ Leucaena $+\left(50 \mathrm{~N}+37.5 \mathrm{P}_{2} \mathrm{O}_{5}+45 \mathrm{~K}_{2} \mathrm{O}\right) ; \mathrm{T}_{7}: 1 \frac{1}{2} \mathrm{t} / \mathrm{h}$ Acacia $+\left(50 \mathrm{~N}+37.5 \mathrm{P}_{2} \mathrm{O}_{5}+\right.$ $\left.45 \mathrm{~K}_{2} \mathrm{O}\right) ; \mathrm{T}_{8}: 1 \frac{1}{2} \mathrm{t} / \mathrm{h}$ Cassia $+\left(50 \mathrm{~N}+37.5 \mathrm{P}_{2} \mathrm{O}_{5}+45 \mathrm{~K}_{2} \mathrm{O}\right) ; \mathrm{T}_{9}: 100 \mathrm{~N}+75 \mathrm{P}_{2} \mathrm{O}_{5}+90 \mathrm{~K}_{2} \mathrm{O} \mathrm{Kg} / \mathrm{ha} ; \mathrm{T}_{10}$ : Absolute control. 
processes taking place during the growth and development of crops [24]. The application of organics alone or in combination with mineral fertilizers led to increased maize grain yield compared to the control. Sole application of leaf biomass of Calliandra spp. and Acacia spp. (umbric Cambisol) and Leucaena spp. and Cassia spp. (ustic Oxisol) generated higher grain yields than the control treatments while the combination of leaf biomass of Calliandra spp. and Acacia spp. (umbric Cambisol) and Leucaena spp. and Cassia spp. (ustic Oxisol) and inorganic fertilizers generated higher grain yields than other treatments (Table 3 ). The higher yields from organic treatments could be attributed to positive effects of organic materials on soil physicochemical properties [14]. The differences in fertilizer technologies that generated higher yields on umbric Cambisol and ustic Oxisol might be related to their nutrient release patterns. These technologies might have released nutrients proportionately to crop demand during growth and development stages which led to greater maize yields. Soil characteristics might have influenced nutrient release patterns of organic residues added to the soil [23].

According to Huang et al. [8], the leafy pruning incorporated into the soil at the beginning of the season decomposed and released nutrients especially nitrogen, which enhanced crop performance and soil characteristics. The integration of organic and inorganic fertilizers might have resulted into synergy and improved synchronization between nutrient release and uptake by plants leading to higher yields [25]. According to Vanlauwe et al. [26] and Afe et al. [24], the production of grain yield might be due to better growth, development and dry matter accumulation with proper supply of nutrients to plant and increase in the availability of other plant nutrients with the respective source of nitrogen application or extra crop produce can often be observed due to positive direct or indirect interactions between fertilizer and organic inputs as suggested by Magda et al. [27]. The inorganic fertilizer provides most of the nutrients and the organic fertilizer increases soil physicochemical properties [17]. The findings of this study are similar with those of Mugendi et al. [28] who found that Leucaena biomass combined with mineral fertilizer gave higher crop yields as compared to sole use of mineral fertilizer or sole Leucaena biomass. These results corroborate with those of Mucheru-Munaet al. [18] who found that Leucaena and Calliandra biomass combined with mineral fertilizer gave higher maize yields as compared to sole use of inorganic fertilizer or Leucaena and Calliandra biomass. These results equally corroborate with those of Zhao et al. [29] who reported that farmyard manure combined with chemical fertilizer resulted in higher increase in maize yield. Similarly, Dilshad et al. [30] and Makinde and Ayoola [31] stated that high and sustainable crop yields are only possible with integrated use of mineral fertilizers with organic matter.

Maize plants in the control plots which did not receive any treatment but submitted under the same ecological conditions (light, amount of water, constant weeding and treatment of insecticides) showed low results as far as grain 
yields are concern. The relatively poor maize grain yields results in the control plots could be partly due to low doses of mineral elements compared to optimal doses used in the experimentation. It could equally be due to the absence of phosphorus in the soil as lack of phosphorus has been particularly identified as a factor limiting the growth of plants. Besides, Baraloto [32] showed that most tropical zones are situated on soils chemically poor, especially in phosphorus and nitrogen. Since the organic materials may often not be available in large amounts that are required for sole application, farmers are encouraged to adopt combined application of leaf biomass and inorganic fertilizers is a better option for increasing fertilizer use efficiency and providing a more balanced supply of nutrients and ultimate yield otherwise higher $\mathrm{N}$ and $\mathrm{P}$ application rates are required to attain better yield in maize [17] [33].

\subsection{Economic Returns of Combined Application of Organic and Mineral Fertilizers on Maize on Umbric Cambisoland Ustic Oxisol over 2 Years}

Averagely across the two cropping seasons, $1 \frac{1 / 2}{2} /$ ha Acacia $+\left(50 \mathrm{~N}+37.5 \mathrm{P}_{2} \mathrm{O}_{5}\right.$ $\left.+45 \mathrm{~K}_{2} \mathrm{O}\right)$ treatmenton umbric Cambisol and $1 \frac{1 / 2}{\mathrm{t}} / \mathrm{ha}$ Cassia $+(50 \mathrm{~N}+37.5$ $\mathrm{P}_{2} \mathrm{O}_{5}+45 \mathrm{~K}_{2} \mathrm{O}$ ) treatment on ustic Oxisol recorded the highest net benefit and return to labor. This could be due to higher yields obtained from positive direct or indirect interactions between fertilizer and organic inputs as suggested by Boukong et al. [22] or lower labor required compared to the sole applications [18]. This study equally showed thatall the treatments that received fertilizers were economically profitable as their benefit to cost ratios were greater than 2 but treatments with sole leaf biomass recorded the higher benefit to cost ratios compared to combined leaf biomass and inorganic fertilizers. This could be attributed to the fact that the cost of organic fertilizer and the labor cost of applying it was lowercompared to combined leaf biomass and inorganic fertilizers. These findings are similar with those of FAO [34], who reported that any treatment that receives fertilizer in an environment where water is not limiting is considered profitable only when its $\mathrm{B} / \mathrm{C}$ ratio is equal to or greater than 2 . These findings are in agreement with those of Mucheru-Muna et al. [18] who reported that Leucaena gave the highest benefit to cost ratio while manure and Tithonia with half recommended rate of inorganic fertilizer gave the lowest. Though $\mathrm{Mu}$ tuo et al. [35] indicated that organics have high labor costs, the results on both soils indicated that treatments that received sole organics and those combining organic and mineral fertilizers (except Calliandra with half recommended rate of mineral fertilizer) recorded a return to labor greaterthan 2.0 , the minimum acceptable for small holder farming activities. Some of the organic materials like Calliandra and Leucaena could be more economically attractive when used as animal feed protein supplement for dairy cattle [5] and the manure returned to the farm. Maximum maize yield, net benefit and return to labor and benefit to cost ratio obtained on ustic Oxisol compared to umbric Cambisol could be at- 
tributed to the soil texture. The differences observed in maize yield, net benefit and return to labor and benefit to cost ratio on umbric Cambisol and ustic Oxisol could be attributed to the type of soil, the sandy soil favored more the $\mathrm{N}$ mineralization and take up processes than the clayey loam or soil nutrient status [18] [36].

\section{Conclusion and Recommendations}

Results from this study divulged that there was a great increase in maize grain yield with the integrated application of organic and inorganic fertilizers relative to the sole use of either of them or the control. Over two years of application of leaf biomass of agroforestry tree species and inorganic fertilizers, 11/2 t/h Acacia and Cassia $+\left(50 \mathrm{~N}+37.5 \mathrm{P}_{2} \mathrm{O}_{5}+45 \mathrm{~K}_{2} \mathrm{O}\right)$ treatments respectively gave the highest maize grain yield, net benefit as well as return to labor while the control gave the lowest yield, net benefit and return to labor on umbric Cambisol and ustic Oxisol. On the other hand, $3 \mathrm{t} / \mathrm{h}$ Acacia spp. and Cassia spp. treatments respectively gave the highest benefit to cost ratios on umbric Cambisol and ustic Oxisol. Maximum maize yield, net benefit, return to labor and benefit to cost ratio were obtained on ustic Oxisol. This work also showed that all treatments that combined leaf biomass and mineral fertilizers were economically profitable except Calliandra with half recommended mineral fertilizers on ustic Oxisol. Farmers are encouraged to adopt combined application of leaf biomass of agroforestry tree species and mineral fertilizer on degraded Cambisols and Oxisols in the Western Highlands of Cameroon to enhance maize grain yields, sustain production at a profitable rate and consequently mitigate climate change. In order to come up with comprehensive recommendations, further research should be conducted considering different varieties, different fertilizer rates and locations.

\section{Acknowledgements}

- The authors greatly acknowledge the authorities of the University of Dschang and IRAD Babungo for granting authorization to carry out this research in their fields.

- The authors are very grateful to Professor Ghogomu Julius Numbonui for funding this project and to Misters Dongmo Wilfred, $N$ for Eric and Mfouapon Hassan for their technical assistance during the execution of the experiments under field condition.

\section{Conflicts of Interest}

The authors declare no conflicts of interest regarding the publication of this paper.

\section{References}

[1] Abd El-Gawad, A.M. and Morsy, A.S.M. (2017) Integrated Impact of Organic and Inorganic Fertilizers on Growth, Yield of Maize (Zea mays L.) and Soil Properties 
under Upper Egypt Conditions. Journal of Plant Production, Mansoura University, 8, 1103-1112. https://doi.org/10.21608/jpp.2017.41121

[2] Ragasa, C., Dankyi, A., Acheampong, P., Wiredu, A.N., Chapoto, A. and Asamoah, M.R. (2013) Patterns of Adoption of Improved Maize Technologies in Ghana. IFPRI, Accra.

[3] Partey, S.T., Thevathasan, N.V., Zougmore, R.B. and Preziosi, R.F. (2018) Improving Maize Production through Nitrogen Supply from Ten Rarely-Used Organic Resources in Ghana. Agroforestry Systems, 92,375-387.

[4] Egbe, E.A., Fonge, B.A., Mokake, S.E., Besong, M. and Fongod, A.N. (2012) The Effects of Green Manure and NPK Fertilizer on the Growth and Yield of Maize (Zea mays L) in the Mount Cameroon Region. Agriculture and Biology Journal of North America, 3, 82-92. https://doi.org/10.5251/abjna.2012.3.3.82.92

[5] Neba, D.A., Suh, C., Mbarga, A.M., Ngome, A.S.F., Fornkwa, V.Y. and Lendzemo, V. (2015) Effect of Tree Hedgerow Pruning on Maize Yield in Santa, Cameroon. International Journal of Agriculture Innovations and Research, 3, 1851.

[6] Yuh, R., Tchoundjeu, Z., Degrande, A. and Kouodiekong, L. (2013) Impact of Organic Soil Amendments on the Physical Characteristics and Yield Components of Potato (Solanum tuberosum L.) in the Highlands of Cameroon. Journal of Agricultural Science and Technology, 3, 257-266.

[7] Barbieri, P.A., Echeverria, H.E., Rozas, H.R.S. and Andrade, F.H. (2008) Nitrogen Use Efficiency in Maize as Affected by Nitrogen Availability and Row Spacing. Agronomy Journal, 100, 1094-1100. https://doi.org/10.2134/agronj2006.0057

[8] Huang, S., Weijian, Z.W., Yu, X. and Huang, Q. (2010) Effects of Long-Term Fertilization on Corn Productivity and Its Sustainability in an Ultisol of Southern China. Agriculture, Ecosystems and Environment, 138, 44-50. https://doi.org/10.1016/j.agee.2010.03.015

[9] Kaho, F., Yemefack, M., Feujio, T.P., Teguefouet, M. and Tchantchaouang, J.C. (2011) Effet combiné des feuilles de Tithonia diversifolia et des engrais inorganiques sur les rendements du maïs et les propriétés d'un sol ferralitique du centre Cameroun. Tropicultura, 29, 39-45.

[10] Tadesse, T., Dechassa, N., Bayu, W. and Gebeyehu, S. (2013) Effects of Farmyard Manure and Inorganic Fertilizer Application on Soil Physicochemical Properties and Nutrient Balance in Rain-Fed Lowland Rice Ecosystem. American Journal of Plant Science, 4, 309-316. https://doi.org/10.4236/ajps.2013.42041

[11] Bibi, Z., Khan, N.U., Akram, M., Khan, O.U., Khan, M.J., Batool, S. and Makhdoom, K. (2010) Maize Response to Integrated Use of NP-Fertilizers and Compost. Pakistan Journal Botany, 42, 2793-2801.

[12] Abdelzaher, M.A., Ibrahim, Z.I., Khalil, F.A. and Mohamed, W.S. (2017) Use of Some Organic and Bio Fertilizers as a Partial Substitution of the Mineral Nitrogen Fertilization for Corn. 1 The Effect on Corn Yield and N, P and K Uptake. Assiut Journal of Agricultural Sciences, 48, 229-250.

https://doi.org/10.21608/ajas.2016.3744

[13] Abbasi, M.K. and Yousra, M. (2012) Synergestic Effects of Biofertilizer with Organic and Chemical N Sources in Improving Soil Nutrient Status and Increasing Growth and Yield of Wheat Grown under Greenhouse Conditions. Plant Biosystems, 146, 181-189. https://doi.org/10.1080/11263504.2012.695296

[14] Mucheru-Muna, M.M., Mugendi, E.D., Kungu'u, E.J., Mugwe, E.J. and Bationo, E.A. (2007) Effects of Organic and Mineral Fertilizer Inputs on Maize Yield and Soil 
Chemical Properties in a Maize Cropping System in Meru South District, Kenya. Agroforest Systems, 69, 189-197. https://doi.org/10.1007/s10457-006-9027-4

[15] Schoebitz, M. and Vidal, G. (2016) Microbial Consortium and Pig Slurry to Improve Chemical Properties of Degraded Soil and Nutrient Plant Uptake. Journal of Soil Science and Plant Nutrition, 16, 226-236. https://doi.org/10.4067/S0718-95162016005000018

[16] Tankou, M.C. (2014) Effect of Green Manure and Intercropping on Potato Production in the Western Highlands of Cameroon. International Journal of Scientific and Technology Research, 3, 204.

[17] Mubeen, K., Iqbal, A., Hussain, M., Zahoor, F., Siddiqui, M.H., Mohsin, A.U., Bakht, H.F.S.G. and Hanif, M. (2013) Impact of Nitrogen and Phosphorus on the Growth, Yield and Quality of Maize (Zea mays L.) Fodder in Pakistan. Philippines Journal of Crop Science, 38, 43-46.

[18] Mucheru-Muna, M.M., Mugendi, E.D., Pypers, P., Mugwe, J., Kungu'u, E.J., Vanlauwe and Merckx, R. (2014) Enhancing Maize Productivity and Profitability Using Organic Inputs and Mineral Fertilizer in Central Kenya Small-Hold Farms. $E_{X}$ plaining Agriculture, 50, 250-269. https://doi.org/10.1017/S0014479713000525

[19] Partey, S.T., Thevathasan, N.V., Zougmore, R.B. and Prezios, R.F. (2016) Improving Maize Production through Nitrogen Supply from Ten Rarely-Used Organic Resources in Ghana. Agroforest Systems, 92, 375-387.

https://doi.org/10.1007/s10457-016-0035-8

[20] Palm, C.A., Gachengo, C.N., Delve, R.J., Cadisch, G. and Giller, K.E. (2001) Organic Inputs for Soil Fertility Management in Tropical Agroecosystems: Application of an Organic Resource Database. Agriculture, Ecosystem and Environment, 83, 27-42. https://doi.org/10.1016/S0167-8809(00)00267-X

[21] Osiname, O.A., Meppe, F. and Everett, L. (2000) Response of Maize (Zea mays L.) to Phosphorous Application on Basilica Soils in North Western of Cameroon. $\mathrm{Nu}$ trient Cycling in Agroecosystems, 56, 209-217. https://doi.org/10.1023/A:1009898521268

[22] Boukong, A., Ghogomu, R., MvondoAwono, J.P., Tabi, F.O. and Meko, G. (2017) Effect of Plant Spacing and Use of Organo-Mineral Fertilisers on Biomass Yield and Profitability of Solanum scabrum Cultivation on an Aquox in the Western Highlands of Cameroon, Agriculture and Biology Journal of North America, 8, 122-131.

[23] Agba, O.A., Ubi, B.E., Abam, P., Ogbechi, J., Akeh, M., Odey, S. and Ogar, N. (2012) Evaluation of Agronomic Performance of Maize (Zea mays L.) under Different Rates of Poultry Manure Application in an Ultisol of Obubra, Cross River State, Nigeria. International Journal of Agriculture and Forestry, 2, 138-144. https://doi.org/10.5923/j.ijaf.20120204.01

[24] Afe, A.L., Atanda, S., Aduloju, M.O., Ogundare, S.K. and Talabi, A.A. (2015) Response of Maize (Zea mays L.) to Combined Application of Organic and Inorganic (Soil and Foliar Applied) Fertilizers. African Journal of Biotechnology, 14, 3006-3010. https://doi.org/10.5897/AJB2015.14808

[25] Muyayabantu, G.M., Kadiata, B.D. and Nkongolo, K.K. (2012) Response of Maize to Different Organic and Inorganic Fertilization Regimes in Monocrop and Intercrop Systems in a Sub-Saharan Africa Region. Journal of Soil Science and Environmental Management, 3, 42-48.

[26] Vanlauwe, B., Descheemaeker, K., Giller, K.E., Huising, J., Merckx, R., Nziguheba, G., Wendt, J. and Zingore, S. (2014) Integrated Soil Fertility Management in Sub-Saharan Africa: Unraveling Local Adaptation. Solid, 1, 1239-1286. 
https://doi.org/10.5194/soild-1-1239-2014

[27] Magda, A.E., Sabar, M.Z. and Mohamed, A.A. (2015) Effect of Mineral Fertilizer Integration with Organic Manure on Growth, Yield and Quality of Maize (Zea mays L.). Journal of Soil Science, Agriculture and Engineering, Mansoura University, 6, 165-179. https://doi.org/10.21608/jssae.2015.41986

[28] Mugendi, D.N., Nair, P.K.R., Mugwe, J.N., O’Neill, M.K. and Woomer, P.L. (1999) Calliandra and Leucaena Alley Cropped with Maize. Part 1. Soil Fertility Changes and Maize Production in the Sub-Humid Highlands of Kenya. Agroforest Systems, 46, 39-50. https://doi.org/10.1023/A:1006288301044

[29] Zhao, Y., Wang, P., Li, J., Chen, Y., Ying, X. and Liu, S. (2009) The Effects of Two Organic Manures on Soil Properties and Crop Yields on a Temperate Calcareous Soil under a Wheat-Maize Cropping System. European Journal of Agronomy, 31, 36-42. https://doi.org/10.1016/j.eja.2009.03.001

[30] Dilshad, M.D., Lone, M.I., Jilani, G., Malik, M.A., Yousaf, M., Khalid, R. and Shamim, F. (2010) Integrated Plant Nutrient Management (IPNM) on Maize under Rainfed Condition. Pakistan Journal of Nutrition, 9, 896-901.

https://doi.org/10.3923/pjn.2010.896.901

[31] Makinde, E.A. and Ayoola, O.T. (2010) Growth, Yield and NPK Uptake by Maize with Complementary Organic and Inorganic Fertilizers. African Journal of Food, Agriculture, Nutrition, and Development, 10, 2203-2217. https://doi.org/10.4314/ajfand.v10i3.54078

[32] Baraloto, C. (2001) Tradeoffs between Tropical Tree Seedling Traits and Performance on Contrasting Environments, Theses, University of Michigan, Ann Arbor, 183.

[33] Vanlauwe, B., Palm, C., Murwira, H. and Merckx, R. (2002) Organic Resource Management in Sub-Saharan Africa: Validation of a Residue Quality-Driven Decision Support System. Journal of Agronomy, 22, 839-846. https://doi.org/10.1051/agro:2002062

[34] FAO (1987) Fertilizer Strategies. Food and Agricultural Organization of the United Nations. FAO Land and Water Development Series, 10-11.

[35] Mutuo, P.K., Mukalama, J.P. and Agunda, J. (2000) On-Farm Testing of Organic and Inorganic Phosphorous Source on Maize in Western Kenya. In: The Biology and Fertility of Tropical Soils, TSBF Annual Report, Nairobi, 22.

[36] Khali, M.I., Hossain, M.B. and Schmidhalte, U. (2005) Carbon and Nitrogen Mineralization in Different Upland Soils of the Subtropics Treated with Organic Materials. Soil Biology and Biochemistry, 37, 1507-1518.

https://doi.org/10.1016/j.soilbio.2005.01.014 